REGULAR ARTICLE

\title{
DETERMINANTS OF TECHNICAL EFFICIENCY OF COTTON FARMERS IN TOGO
}

\author{
Essossinam ALI *1 (iD), Komi Tchotoubai KPAKPABIA ${ }^{2}$ (iD
}

\author{
Address: \\ ${ }^{1}$ Department of Economics, University of Kara, Kara, Togo \\ ${ }^{2}$ Nouvelle Société Cotonnière du Togo \\ * Corresponding author: joachimali@hotmail.fr
}

\begin{abstract}
Cotton is a cash crop that occupies an important place in Togolese economy. However, a downward trend in productivity has been observed over the last twenty years, but the reasons are not well known. The purpose of this article is to determine the level of technical efficiency of cotton producers and analyse its determinants. The stochastic frontier analysis was adopted and data collected from 150 cotton producers in five regions in Togo was used. The results show that the average technical efficiency of cotton producers is $48.33 \%$. It is therefore possible to increase the level of cotton production to $51.67 \%$ using the available resources. The factors that affect the technical inefficiency of farmers include the use of herbicides, the education level and the nature of the soil. In order to increase the productivity of cotton, policy should target on the capacity building of the producers by an effective support of the extension agents in order to ensure the follow-up of the technical itineraries.
\end{abstract}

Keywords: Agriculture, Technical efficiency, Cotton, Togo JEL: Q1, D13; D61, E23

\section{INTRODUCTION}

At the industry level, the resources managements are a key element for its development. Agriculture, as an industry, also needs an efficient use of resources in order to sustainably increase income and reduce poverty while improving agricultural productivity. For instance, Christiaensen (2017) finds that increasing productivity requires rational or efficient use of resources as supports the neoclassical production theory. The rational behaviour is therefore a key factor of productivity and producers' income while contributing to the development dynamics. Indeed, the agricultural sector continues to be the key driver of economic and social development for most developing countries (Dorosh and Thurlow, 2018; Christiaensen et al., 2011). According to Diao et al. (2010), agriculture employs more than $60 \%$ of the workforce and contributes more than $35 \%$ of the gross domestic product (GDP) of most African countries and more than $40 \%$ for the least developed countries. In most developing countries, agricultural products fulfil food security and play an important role in income generation and meet farmers' subsistence needs (Sun and Li, 2018; Christiaensen et al., 2011; Valdés and Foster, 2010). Moreover, agricultural products, mainly cash crops, account for a significant share of exports (Narayan and Bhattacharya, 2019).

Cotton is recognized as one of the most widely grown cash crops in the world (Fatima et al., 2016; Sarker and Alam, 2016; Mensah, 2015; Lyford, 2009; Baffes, 2005). Cotton is mainly grown on rain-fed land by smallholder farmers. It plays an important role in the livelihoods of rural households as it generates income for smallholder farmers, improves rural welfare and contributes to economic growth (Sodjinou et al., 2015; Sneyd, 2015; Badiane et al., 2002). In Sub-Saharan Africa, cotton remains a strategic crop and constitutes the white gold and accounts for $13 \%$ of world exports between 2002 and 2003 (IFM, 2014; Goreux 2003). Between 1998 and 1999, the share of cotton in exports accounted for between $30 \%$ and $44 \%$ of exports in five West African countries: Benin, Burkina Faso, Chad, Mali and Togo (Baffes, 2005). In 2000, cotton accounted for about 5\% of GDP for Mali and Chad and on average $4.9 \%$ of GDP for Togo and its share in total agricultural exports was about 70.5\% for Togo (Fortucci, 2003). According to Mensah (2015), between 1991 and 2009, the share of cotton exports in total cash crop exports (cotton, cocoa and green coffee) in Togo was about $88 \%$ or $16 \%$ of total exports (all commodities included). These data show that cotton export alone represents about 5\% of GDP.

However, there is a persistent decline in cotton productivity in Togo according to data from NSCT (2017). Indeed, from 1998 to 2017, it appears that cotton production in Togo has a downward trend (Fig. 1). Several factors may explain this decline, in particular technical factors as well as farmers' socio-economic characteristics. This requires an analysis of the allocation of productive resources in the sector. For example, Ali and Byerlee (1991) have shown that the adoption of new technologies is subject to significant technical inefficiency leading to a decrease of productivity. Alternatively, Olmstead and Rhode (2008) have shown that the development and adoption of new cotton varieties were the main sources of increase of efficiency of cotton production in the case study of South America. The lack of sufficient information 
on the new technologies available to farmers can explain these differences in the adoption of new technologies affecting productivity (Piesse and Thirtle, 2000).

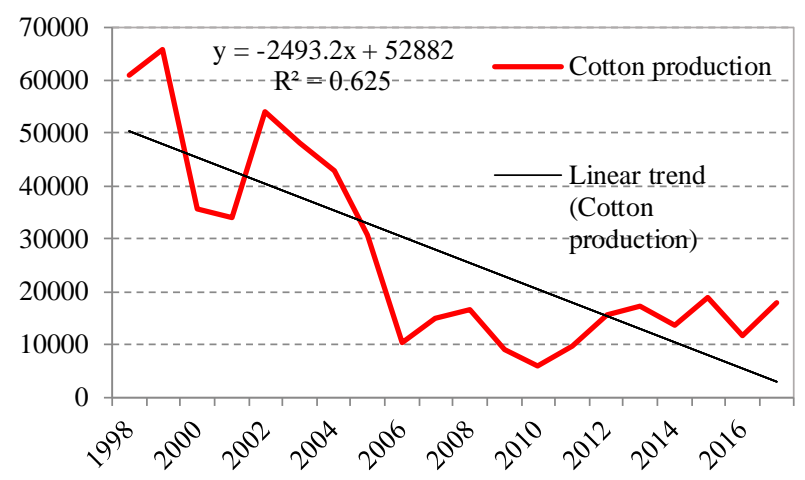

Figure 1: Trend of cotton production in Togo (1998-2017) Source: Authors design based on data from NSCT (2017)

On the other hand, the allocation of resources such as fertilizer, land, labor (Sarker and Alam, 2016, Bojnec and Latruffe, 2013; Binici et al., 2006a; Rizov et al., 2001) and socio-economic and institutional factors such the access to extension services, the education level, and the amount of credit can be determinants of the level of production (Sarker and Alam, 2016; Karimov, 2014; Sauer and Balint, 2008; Sauer, 2006). Better management of resources and well organization and management of the farm would increase productivity (Theodoridis et al., 2014; Karimov, 2012; Binici et al., 2006b; Coelli et al., 2002).

However, there is little knowledge of how resources are used in the cotton production process in Togo except some work by Koffi-Tessio (2000) who finds that the price is not a determinant of cotton supply; and Mensah (2015) who only addresses the issues of impact of cotton price variability on cotton farmers' welfare. It is therefore important to understand the sources of low level cotton production in the sector in order to propose actions or policies likely to boost cotton production in Togo and increase farmers' income and reduce vulnerabilities. The current challenge needs to improve the performance of cotton producers in order to increase producers' incomes.

The main objective of this study is to evaluate the performance of cotton producers in terms of resources allocation in cotton farming. Specifically, the study aims to determine the level of technical efficiency of cotton producers in Togo and analyses the main determinants of the technical efficiency of cotton producers in the study area.

\section{DATA AND METHODS}

\section{Theoretical and conceptual frameworks}

The problem of technical efficiency has long been a concern for many researchers in various fields such as health (Kuntz et al., 2007), finance (Weill, 2002) and agriculture (Fontan, 2008; Coelli et al., 2002). Efficiency refers to the ability to achieve a goal. In production theory, the term efficiency refers to the ability of producers to achieve a good performance in a given type of task. In our context, the technical efficiency of cotton production can be defined as the ability to obtain the highest level of production given the available resources. The question of the technical efficiency of cotton production can be attributed to several causes including the lack of access to extension services, the lack of incentives for producers, the non-respect of the technical itinerary, the choice of sowing period, and the under-use or over use of inputs such as seeds, fertilizer, pesticides and herbicides (Rasse et al., 2018, Chogou et al., 2017; Rapidel et al., 2009). It is therefore necessary to understand the drivers of inefficiency and enable the decision-makers to take actions in order to improve the overall efficiency of the sector.

Although the issue of efficiency is of interest to the wide range of researchers, several debates arise when it comes to the choice of the estimation technique. Two techniques are often discussed (Lovell and Schmidt, 1988). On the one hand, the data envelopment technique or deterministic approach (Farrell, 1957; Charnes et al., 1978; Shafiq and Rehman, 2000) and the stochastic frontier approach on the other hand (Coelli et al., 1998; Coelli et al., 2002; Weill, 2003). Like deterministic approach, the stochastic frontier approach leads to the computation of a specific technical efficiency score for each production unit (Farrell, 1957; Shafiq and Rehman, 2000; Coelli et al., 2002). This involves estimating the stochastic frontier or specifying a regression model relating each of the score of a firm's efficiency in a given period and producer's socioeconomic characteristics. However, this procedure has been disputed in the literature (Coelli, 2002; Battese and Coelli, 1995, Sexton et al., 1986; Farrell, 1957). Indeed, the estimation of the parameters in the second step contradicts a hypothesis made in the first stage (Sexton $\boldsymbol{e t}$ al., 1986). To overcome this gap, various studies have led to models that make it possible to simultaneously estimate the stochastic production frontier and the factors that explain the differences in technical efficiency between firms (Coelli, 2002). This approach will be used in this context.

\section{The sampling technique and method of data collection}

The sampling was done in such a way to take into account the producers of the 5 administrative regions in Togo. One hundred and sixty cotton producers were randomly chosen in cotton based famers' groups (thirty two farmers in each region). The list of producers was provided by the Cotton Company of Togo (NSCT) thanks to the regional Directorates through the Technico-Commercial Agent (ATC) which is a grouping of several cotton farmers based organization under the control of a technical agent of each region. The structured questionnaire previously pre-tested was used to collect data. The questionnaire includes open, semi-closed and closed questions that are designed to measure variables that fall within the definition of the production function. Finally, 150 well-filled questionnaires were considered for the analysis. The other 10 questionnaires were rejected because all the questions were not answered. The econometric analysis was done using the FRONTIER software (Version 4.1c). 


\section{The econometric approach}

This study uses the stochastic frontier approach proposed by Aigner et al. (1977), Meeusen and Van Den Broek (1977), and improved by Jondrow et al. (1982). The advantage is that, this approach allows the estimation of technical efficiency score specific to each production unit while taking into account the variables that cannot be controlled by farmers (socioeconomic characteristics). Following the method of Battese and Coelli (1995), the individual production function can be written in the form of Eq.1.

$Y_{i}=f\left(X_{i} \beta\right) \exp \left(V_{i}-U_{i}\right)$

Where: $\boldsymbol{Y}_{\boldsymbol{i}}$ represents the quantity of cotton produced in tons. $\boldsymbol{X}_{\boldsymbol{i}}$ is the row matrix of exogenous or input variables used in cotton production while $\boldsymbol{\beta}$ is the column vector of the parameters to be estimated. $\boldsymbol{V}_{\boldsymbol{i}}$ is the random error term assumed to be identically and independently distributed. $\boldsymbol{U}_{\boldsymbol{i}}$ is a linear function of the explanatory variables related to the technical inefficiency of the production units (Eq. 2Eq.3).

$$
\begin{aligned}
& T E_{i}=\frac{\text { Production of the farm } \mathrm{i}}{\text { Maximum of the farm } \mathrm{i}}=\frac{f\left(X_{i} \beta\right) \exp \left(V_{i}-U_{i}\right)}{f\left(X_{i} \beta\right) \exp \left(V_{i}\right)} \\
& T E_{i}=\exp \left(-U_{i}\right)
\end{aligned}
$$

Where: $T E_{i}$ is the technical efficiency of the farm i. it is assumed to be a linear function of the exogenous variables that can explain the existence of inefficiency of farmers in cotton production.

In order to simplify the analysis and interpretation of the relationship between the dependent variable and the explanatory variables, Cobb-Douglas functional form is adopted (Jondrow et al., 1982). The Cobb-Douglas technology can be written as Eq. 4 - Eq. 5 .

$$
Y_{i}=A X_{1}^{\beta_{1}} X_{2}{ }^{\beta_{2}} X_{3}{ }^{\beta_{3}} X_{4}{ }^{\beta_{4}} X_{5}{ }^{\beta_{5}} e_{t}
$$

$\ln Y_{i}=\beta_{0}+\beta_{1} \ln X_{1}+\beta_{2} \ln X_{2}+\beta_{3} \ln X_{3}+\beta_{4} \ln X_{4}+$

$\beta_{5} \ln X_{5}-U_{i}+V_{i}$

Where: $X_{1}$ is the cultivated land for cotton crop in hectare, $X_{2}$ is the amount of insecticide and herbicide used, $X_{3}$ stands for total amount of labour used per farm and measured in man-day, $X_{4}$ is the amount of fertilizer used, $X_{5}$ is the number of kilogram of seeds used per hectare. $\beta_{0}=\ln A$ captures the effect of technological change cotton production.

However, the determinants of the technical inefficiency of cotton producers which is a linear function of the exogenous variables (socioeconomic variables) can be written as Eq. 6.

$Z_{i}=\alpha_{0}+\alpha_{1} \gamma_{1}+\alpha_{2} \gamma_{2}+\alpha_{3} \gamma_{3}+\alpha_{4} \gamma_{4}+\alpha_{5} \gamma_{5}+$ $\alpha_{6} \gamma_{6}+\alpha_{7} \gamma_{7}+\alpha_{8} \gamma_{8}+\alpha_{9} \gamma_{9}+\alpha_{10} \gamma_{10}+\alpha_{11} \gamma_{11}+$ $\alpha_{12} \gamma_{12}+\mu_{i}$

Where: $Z_{i}$ defines the average efficiency of each producer $(\mathrm{i}=1,2,3, \ldots, \mathrm{n}) ; \quad \gamma_{1}$ represents the socio-economic variables that can explain the technical inefficiency of the producers and $\alpha_{i}$ are the parameters to be estimated ( $\mathrm{i}=$ $1,2, . ., 12)$.

\section{Choice of variables}

The selected variables gathering the production and farmers' socioeconomic characteristics and their expected

\begin{tabular}{|c|c|c|}
\hline Variables & Unit & $\begin{array}{l}\text { Expected } \\
\text { sign }\end{array}$ \\
\hline \multicolumn{3}{|l|}{ Production variables } \\
\hline $\begin{array}{l}\text { Quantity of cotton } \\
\text { produced }\left(\mathrm{Y}_{\mathrm{i}}\right)\end{array}$ & Number of tons & \\
\hline Cultivated area $\left(X_{1}\right)$ & $\begin{array}{l}\text { Number of } \\
\text { hectares }\end{array}$ & + \\
\hline $\begin{array}{l}\text { Quantity of applied } \\
\text { pesticide }\left(X_{2}\right)\end{array}$ & Number of liters & $+/-$ \\
\hline Labor $\left(X_{3}\right)$ & Total man-days & + \\
\hline $\begin{array}{l}\text { Quantity of } \\
\text { fertilizer }\left(X_{4}\right)\end{array}$ & $\begin{array}{l}\text { Number of } \mathrm{Kg} \\
\text { used }\end{array}$ & + \\
\hline $\begin{array}{l}\text { Quantity of seed } \\
\text { used }\left(X_{5}\right)\end{array}$ & $\begin{array}{l}\text { Number of } \mathrm{Kg} \\
\text { used } \\
\text { per hectare }\end{array}$ & $+/-$ \\
\hline \multicolumn{3}{|c|}{ Socioeconomic variables } \\
\hline Age $\left(\gamma_{1}\right)$ & Number of years & $+/-$ \\
\hline $\operatorname{Sex}\left(\gamma_{2}\right)$ & $\begin{array}{l}1=\text { Man, } \\
0=\text { Woman }\end{array}$ & $+/-$ \\
\hline Experience $\left(\gamma_{3}\right)$ & Number of years & - \\
\hline $\begin{array}{l}\text { Quantity of } \\
\text { pesticides }\left(\gamma_{4}\right)\end{array}$ & Number of liters & $+/-$ \\
\hline Primary school $\left(\gamma_{5}\right)$ & $\begin{array}{l}1=\text { Primary, } \\
0=\text { Otherwise }\end{array}$ & - \\
\hline $\begin{array}{l}\text { Secondary school } \\
\left(\gamma_{6}\right)\end{array}$ & $\begin{array}{l}1=\text { Secondary } \\
0=\text { Otherwise }\end{array}$ & - \\
\hline $\begin{array}{l}\text { Member of cotton } \\
\text { farmers } \\
\text { based organization } \\
\left(\gamma_{7}\right)\end{array}$ & $1=$ Yes, $0=$ No & - \\
\hline $\begin{array}{l}\text { Assisted by } \\
\text { extension agent }\left(\gamma_{8}\right)\end{array}$ & $1=$ Yes, $0=$ No & - \\
\hline Sandy land $\left(\gamma_{9}\right)$ & $1=$ Yes, $0=$ No & $+/-$ \\
\hline Clayed land $\left(\gamma_{10}\right)$ & $1=$ Yes, $0=$ No & $+/-$ \\
\hline $\begin{array}{l}\text { Household size } \\
\left(\gamma_{11}\right)\end{array}$ & $\begin{array}{l}\text { Number of } \\
\text { persons } \\
\text { in the household }\end{array}$ & $+/-$ \\
\hline $\begin{array}{l}\text { Other activity than } \\
\text { agriculture }\left(\gamma_{12}\right)\end{array}$ & $1=$ Yes, $0=$ No & $+/-$ \\
\hline
\end{tabular}
signs used in this study are described in Table 1.

Table 1: Variables, the measurements and expected signs

In this paper, the output is the total amount of cotton produced and measured in tons. The cultivated area, measured in terms of hectare, can positively affect the level of cotton produced. The same hypothesis is set for labour and the amount of fertilizer used. The assistance of extension agent can help to increase productivity by assuring the respect of technical itinerary. The education level and the structure of the land could also be determinants (Yang et al., 2016). 


\section{RESULTS AND DISCUSSION}

The deterministic factors are described in Table 2 . The average cultivated land for the surveyed farm households was about 2.59 hectares with a minimum of 0.5 hectares and the maximum reaching 9 hectares. The average variability of cultivated land between producers was about 2.59 hectares. The chemical fertilizer is mostly used in cotton farming and determinant of cotton yields (Honfoga, 2018; Zulfiqar and Thapa, 2016; Soomro et al., 2000). The average fertilizer used per producer was about 507 kilograms with a maximum reaching 1750 kilograms. However, the average applied fertilizer per hectare was about 200 kilograms. The lowest dose was 67 kilograms per hectare and the highest reaching 600 kilograms per hectare which is three times of the average dose of the surveyed households.

The average yield of cotton producers in the sample was approximately 1153 kilograms per hectare. This yield is higher than the average observed during the last twenty years is 933 kilograms per hectare (NSCT, 2017) with a large standard deviation (535.31 kilograms per hectare). The quantity of seed used per producer was on average 117 kilograms per hectare with a minimum of 25 kilograms and a maximum reaching 400 kilograms. The average seed dose used on the plots was 43 kilograms per hectare. The seeds used per hectare were relatively higher than the recommended quantity of seed to be used in Togo (25 kilograms per hectare) according to NSCT (2017).

Socio-demographic variables of cotton farmers in Togo The socio-demographic characteristics of the respondents are presented in Table 3. The cotton farmers in the sample are relatively young (on average, 43 years old). However, most of them are well experienced in cotton production (12 years on average). The results show that $43.83 \%$ of cotton farmers in the sample have a formal education and agriculture still remains the main activity of most producers $(61.64 \%)$.

Table 2: Descriptive statistics of production variables

\begin{tabular}{|c|c|c|c|c|c|c|c|}
\hline Variables & Production & Seed & $\begin{array}{l}\text { Cultivated } \\
\text { area }\end{array}$ & Fertilizer & Insecticides & Herbicides & Labour \\
\hline Unit & $\begin{array}{l}\text { Number of } \\
\mathrm{kg}\end{array}$ & $\begin{array}{l}\text { Number } \\
\text { of } \mathrm{kg}\end{array}$ & $\begin{array}{l}\text { Number of } \\
\text { hectares }\end{array}$ & $\begin{array}{l}\text { Number } \\
\text { of } \mathrm{kg}\end{array}$ & $\begin{array}{l}\text { Number of } \\
\text { liters }\end{array}$ & $\begin{array}{l}\text { Number of } \\
\text { liters }\end{array}$ & $\begin{array}{l}\text { Number of } \\
\text { man-days }\end{array}$ \\
\hline \multicolumn{8}{|c|}{ Average per producer } \\
\hline Mean & 3372 & 117 & 2.59 & 507 & 8.39 & 4.48 & 34 \\
\hline $\begin{array}{l}\text { Standard } \\
\text { deviation } \\
\text { (SD) }\end{array}$ & 2770.3 & 77.34 & 2.59 & 288.70 & 5.15 & 4.4 & 34 \\
\hline Minimum & 284 & 25 & 0.5 & 100 & 1.2 & 0.00 & 19 \\
\hline Maximum & 46902 & 400 & 9 & 1750 & 33 & 21 & 60 \\
\hline \multicolumn{8}{|c|}{ Average per hectare } \\
\hline Mean & 1153.81 & 43 & - & 200 & 3.39 & 1.41 & 19 \\
\hline SD & 535.31 & 14.04 & - & 45.16 & 1.29 & 1.3 & 10.12 \\
\hline Minimum & 94.66 & 8.33 & - & 67 & 1 & 0.00 & 4 \\
\hline Maximum & 9380 & 100 & - & 600 & 8.7 & 5.33 & 66 \\
\hline
\end{tabular}

All producers belong to a cotton based farmers organization while $50.68 \%$ belong to other farmers' organizations (Table 3). Moreover, most of farmers in the sample $(86.30 \%)$ have at least been assisted by an extension services. This participation rate is expected to reduce the inefficiency of most farmers in the sample.

\section{Estimation of marginal risks of cotton production}

The analysis of the coefficients of the production variables shows that cotton production is determinant of the cultivated area, the amount of pesticide used, the labour and the amount of fertilizer applied (Table 4). The cultivated area and the amount of insecticide used are significant at $1 \%$ level. This means that a $1 \%$ increase in the cultivated land will lead to an increase in cotton production by $44.30 \%$. The land allocation within other crops (subsistence crops against cash crops) at the household level can be a key determinant regarding the revenue generated from each crops.

The coefficient of the amount of insecticide sprayed is significant at $1 \%$ level and positively correlated to the cotton production. This implies that a $1 \%$ increase in applied insecticide would increase production by $713.04 \%$ (Table 4). This result is consistent with those from (Gouda et al., 2018) who find that increasing the pesticide use would increase cotton production in the case study of Benin with similar socioeconomic characteristics. However, the health and environmental issues can be raised (Taiwo, 2019; Donga and Eklo, 2018; Brouwer $\boldsymbol{e t}$ al., 2017). Getting these producers to better understand the benefits of this operation would substantially increase production.

\section{Estimation of the determinants technical efficiency}

There can be factors that farmers cannot control. These factors include farmers' socio-demographic characteristics. These factors can significantly influence the technical efficiency of cotton production (Table 5).

Source: Authors, using field survey data, 2018 
Table 3: Socio-demographic characteristics of the surveyed cotton farmers in Togo

\begin{tabular}{|c|c|c|c|c|c|}
\hline \multirow{2}{*}{\multicolumn{6}{|c|}{$\begin{array}{l}\text { Variables } \\
\text { Quantitative variables }\end{array}$}} \\
\hline & & & & & \\
\hline \multicolumn{6}{|c|}{ Age Num } \\
\hline Household size & Household members & 3 & 13 & 6 & 1.51 \\
\hline Experience & Number of years & 1 & 32 & 12 & 6.38 \\
\hline \multicolumn{6}{|c|}{ Qualitative variables } \\
\hline \multicolumn{2}{|l|}{ Variables } & \multicolumn{2}{|l|}{ Unit } & \multicolumn{2}{|c|}{ Frequency $(\%)$} \\
\hline \multicolumn{2}{|l|}{ Sex } & \multicolumn{2}{|c|}{$(1=$ Man; 0=Woman) } & & 92.50 \\
\hline \multicolumn{2}{|c|}{ Formal education } & \multicolumn{2}{|c|}{$(1=$ Yes $; 0=\mathrm{No})$} & & 43.83 \\
\hline \multicolumn{2}{|l|}{ Principal activity } & \multicolumn{2}{|c|}{ ( $1=$ Agriculture $; 0=$ Other $)$} & & 61.64 \\
\hline \multicolumn{2}{|c|}{ Member of cotton based farmers organization } & \multicolumn{2}{|c|}{$(1=$ Yes, $0=\mathrm{No})$} & & 100.00 \\
\hline \multicolumn{2}{|c|}{ Member of other cotton based farmers organization } & \multicolumn{2}{|c|}{$(1=$ Yes; $0=$ No $)$} & & 50.68 \\
\hline \multicolumn{2}{|c|}{ Assisted by extension agent } & \multicolumn{2}{|c|}{$(1=$ Yes; $0=\mathrm{No})$} & & 86.30 \\
\hline
\end{tabular}

Source: Authors, using field survey data, 2018

Table 4: Determinants of cotton production in Togo

\begin{tabular}{lrrr}
\hline Variables & Coeff & Std Error & T-Ratio \\
\hline Constant & $-288.76^{* * *}$ & 1.46 & -197.75 \\
$\ln ($ Cultivated area) & $44.30^{* * *}$ & 1.07 & 41.16 \\
$\ln$ (Quantity of pesticides used) & $713.04 * * *$ & 3.19 & 222.89 \\
$\ln ($ Labor) & -24.78 & 22.70 & -1.09 \\
$\ln ($ Quantity of fertilizer used) & 0.58 & 1.97 & 0.29 \\
$\ln$ (Quantity of seed used) & -3.37 & 7.40 & -0.45 \\
\hline
\end{tabular}

Source: Field survey data, 2018. Note: $* * * \mathrm{P}<0.01$

Table 5: Estimation of determinants of technical efficiency

\begin{tabular}{|c|c|c|c|}
\hline Variables & Coeff & Std err & T-Ratio \\
\hline Constant & $-4.02 * * *$ & 1.60 & -2.50 \\
\hline Age & -29.32 & 21.13 & -1.38 \\
\hline Experience & $127.38 * * *$ & 34.36 & 3.70 \\
\hline $\begin{array}{l}\text { Quantity of } \\
\text { pesticides }\end{array}$ & $151.89 * * *$ & 41.93 & 3.62 \\
\hline Sex & $-4.30 * * *$ & 1.67 & -2.57 \\
\hline Primary & $3.53 * * *$ & 1.47 & 2.39 \\
\hline Secondary & $10.53 * * *$ & 3.27 & 3.21 \\
\hline $\begin{array}{l}\text { Member of cotton } \\
\text { based } \\
\text { farmers } \\
\text { organization }\end{array}$ & -1.19 & 1.16 & -1.02 \\
\hline $\begin{array}{l}\text { Number of } \\
\text { extension } \\
\text { agent visits }\end{array}$ & $16.04 * * *$ & 4.71 & 3.40 \\
\hline Sandy land & $-20.98 * * *$ & 6.08 & -3.45 \\
\hline Clayey land & $4.99 * * *$ & 1.76 & 2.83 \\
\hline Households size & $96.14 * * *$ & 27.16 & 3.53 \\
\hline $\begin{array}{l}\text { Other activity than } \\
\text { agriculture }\end{array}$ & $10.58 * * *$ & 3.25 & 3.25 \\
\hline Sigma-square & $\begin{array}{r}17692229 * \\
* *\end{array}$ & 1 & $\begin{array}{r}176922 \\
26\end{array}$ \\
\hline Gamma & $1.77 \mathrm{E}-05$ & $\begin{array}{r}9.13 \mathrm{E}- \\
05\end{array}$ & 0.19 \\
\hline Log likelihood & -1418.99 & & \\
\hline Test de LR & 8.16 & & \\
\hline
\end{tabular}

Source: Authors, using field survey data, 2018. Note: ***P $<0.01$

Having at least a primary or secondary education affects significantly and positively cotton production level. This implies that higher education level helps farmers in understanding and adopting new technologies that require a steady of some itinerary techniques. Therefore, high education increases the technical efficiency of farmers in production process. This result is similar to those of Abdulai et al. (2018) in the case study of Northern Ghana. The education level, coupled with the regular visit of extension agents in cotton production, increases significantly the technical efficiency of cotton farmers. The results show that, an increase of $1 \%$ of the number of visits by extension agent increases cotton production efficiency by $16.04 \%$. The assistance of an extension agent is a factor that decreases the inefficiency of producers significantly. With advice from extension agents, production techniques are improved and producers are more efficient. The quantity of herbicide used has a positive sign and is significant at $1 \%$ threshold. This means that increasing the pesticide use by $1 \%$ will increase the technical efficiency of cotton farmers by $151 \%$. However, the type of soil is determinant. For instance, the results show that growing cotton on sandy land decreases the technical efficiency of cotton farmers compared to the clayey land that has a positive effect.

\section{The efficiency score}

The efficiency score is shown in Figure 2. The results show that most of the farmers in the study areas are technically inefficient. The lowest score of technical efficiency of cotton producers was on average about $5.37 \%$ while the most rational producer has an efficiency score about $82.08 \%$ (Fig. 2). To make all producers efficient, the cost of cotton production can be reduced by $94.63 \%$ without additional resources. The results therefore show that there is a lot of space in this case to boost cotton 
production. The average technical efficiency score of the sample is $48.33 \%$. This result shows that it is possible to increase the average production by $51.67 \%$ without additional resources.

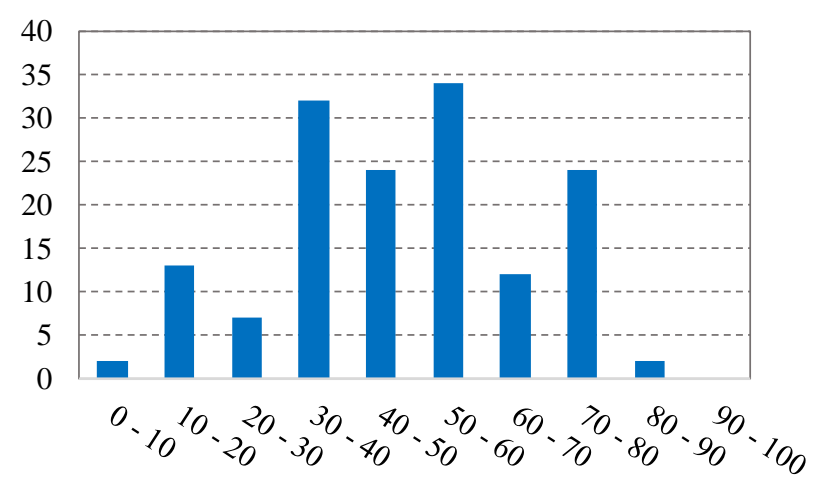

Figure 2: Distribution of technical efficiency scores of cotton farmers in Togo $(\%)$

Source: Authors design, using field survey data, 2018

To be technically efficient, producers should reduce their cost of production by about $51.67 \%$. These results show that there is a great possibility to boost the cotton production. This can be achieved by adopting the best farming practices of production and the follow-up of the technical itineraries would be the first target while supports from the extension services are needed.

\section{CONCLUSIONS}

Considered as the development engine for most developing countries, the agricultural sector plays an important role in poverty reduction given its contribution to the Togolese economy. The cash crops, especially cotton production, are an important source of currency inflows to the country. Unfortunately, the dow nward trend in cotton production over the last twenty years is observed, but reasons behind this sagging level of productivity are not well understood. The general objective of this paper is to analyse the performance of producers in cotton production in Togo. More specifically, this study determines the level of technical efficiency of cotton producers and to analyse the determinants of this efficiency. For this purpose, the data was collected from 150 randomly selected farmers in the 5 regions of Togo using a structured questionnaire administered. The stochastic frontier approach is used to achieve the assigned objectives.

The results reveal that the average technical efficiency of the producers in the sample was $48.33 \%$. One can conclude that, it is possible for producers to reduce production costs by $51.67 \%$ with available resources. The determinants of technical efficiency that have a significant impact on production include production experience, the amount of herbicide used, education level, and the assistance of extension services. Considering the gender aspect, the results show that women are technically more efficient than men. The nature of the soil, the size of the household and respondent's main activity were also determinants.
In order to increase the productivity of cotton, the capacity building of the producers by an effective support of the extension agents is recommended to ensure the follow-up of the technical itineraries. The gender aspect should also be taken into account in policy dealing with cotton production in the study areas. Moreover, encouraging farmers' education would be an asset in reducing inefficiency in the use of available resources and significantly increasing production. An in-depth study on the nature of soils would be an asset for better adaptation of crops and orientation of producers in their land allocation to different crops.

\section{Acknowledgements}

The authors would like to thank respondent farmers who were willing to provide their time for interviews. The authors also would like to thank Mr. Theophile Twagirayesu from Central Bank of Rwanda and Genesis B. Kollie from University of Liberia for their constructive comments and suggestions.

\section{REFERENCES}

ABDULAI, S., NKEGBE, P.K., \& DONKOH, S. A. (2018). Assessing the technical efficiency of maize production in Northern Ghana: The data envelopment analysis approach. Cogent Food and Agriculture 4(1). DOI: https://doi.org/10.1080/23311932.2018.1512390 AIGNER, D. J., LOVELL, C. A. K., \& SCHMIDT, P. (1977). Formulation and estimation of stochastic frontier production function models. Journal of Econometrics 1(6): 21-37. DOI: https://doi.org/10.1016/03044076(77)90052-5

ALI, M., \& BYERLEE, D. (1991). Economic efficiency of small farmers in a changing world: A survey of recent evidence. Journal of International Development, 3(1): 127. DOI: https://doi.org/10.1002/jid.4010030102

BADIANE, O., GHURA, D., GOREUX, L., \& MASSON, P. (2002). Cotton sector strategies in West and Central Africa. Policy Research Working Paper, No.2867. World Bank, Washington, DC.

BAFFES, J. (2005). Cotton: Market setting, trade policies and issues. In Aksoy A.M., and Beghin J.C.(Eds): Global agricultural trade and developing countries, pp 258-273 BATTESE, G., \& COELLI, T. (1995). A model for technical inefficiency effects in a stochastic frontier production function for panel data. Empirical Economics 20(2): 325-332. DOI: https://link.springer.com/article/10.1007/BF01205442 BINICI, T., DEMIRCAN, V., \& ZULAUF, C.R. (2006a). Assessing production efficiency of dairy farm in Burdur province, Turkey. Journal of Agriculture and Rural Development in the Tropics and Subtropics, 107(1): 1-10 BINICI, T., ZALAUF, C. R., KACIRA, O. O., \& KARLI, B. (2006b). Assessing the efficiency of cotton production on the Harran Plain, Turkey. Outlook on Agriculture 35(3), 227-232. DOI: https://doi.org/10.5367\%2F000000006778536729

BOJNEC, Š., \& LATRUFFE, L. (2013). Farm size, agricultural subsidies and farm performance in Slovenia. Land Use Policy 32: 207-2017. DOI: https://doi.org/10.1016/j.landusepol.2012.09.016 
BROUWER, M., HUSS, A., DER MARK, M., NIJSSEN, P. C. G., MULLENERS, W. M., SAS, A. M. G., VAN LAAR, T., DE SNOO, G. R., KROMHOUT, H., \& VERMEULEN, R. C. H. (2017). Environmental exposure to pesticides and risk of Parkinson's disease in the Netherlands. Environment International 107: 100-110. DOI: https://doi.org/10.1016/j.envint.2017.07.001

CHARNES, A., COOPER, W. W., \& RODES, E. (1978). Measuring the efficiency of decision making units. European Journal of Operational Research, 2(6): 429444. DOI: https://doi.org/10.1016/0377-2217(78)90138-8 CHOGOU, S. K., GANDONOU, E., \& FOGBE, N. (2017). Mesure de l'efficacité technique des petits producteurs d'ananas au Benin. Cahiers Agricultures, 26, 25004. DOI: https://doi.org/10.1051/cagri/2017008

CHRISTIAENSEN, L. (2017). Agriculture in AfricaTelling myths from facts: A synthesis. Food Policy 67: 111. DOI: https://doi.org/10.1016/j.foodpol.2017.02.002 CHRISTIAENSEN, L., DEMERY, L., \& KUHL, J. (2011). The (evolving) role of agriculture in poverty reduction-An empirical perspective. Journal of Development Economics, 96(2): 239-254. DOI: https://doi.org/10.1016/j.jdeveco.2010.10.006

COELLI, T., RAHMAN, S., \& THIRTLE, C. (2002). Technical, allocative, cost and scale efficiencies in Bangladesh rice cultivation: A non-parametric approach. Journal of Agricultural Economics 53(3): 607-626. DOI: https://doi.org/10.1111/j.1477-9552.2002.tb00040.x

COELLI, T., RAO, D. S. P., \& BATTESE, G. E. (1998). An introduction to efficiency and productivity analysis. Kluwer, Boston

DIAO, X., HAZELL, P., \& THURLOW, J. (2010). The role of agriculture in African development. World Development, $\quad 38(10), \quad$ 1375-1383. DOI: https://doi.org/10.1016/j.worlddev.2009.06.011

DONGA, K. T., \& EKLO, O. M. (2018). Environmental load of pesticides used in conventional sugarcane production in Malawi. Crop protection, 108: 71-77. DOI: https://doi.org/10.1016/j.cropro.2018.02.012

DOROSH, P., \& THURLOW, J. (2018). Beyond agriculture versus non-agriculture: Decomposing sectorial growth-poverty linkages in five African countries. World Development, 109: 440-451. DOI: https://doi.org/10.1016/j.worlddev.2016.08.014

FATIMA, H., KHAN, M. A., ZAID-ULLAH, M., JABBAR, A., \& SADDOZAI, K. N. (2016). Technical efficiency of cotton production in Pakistan: A comparative study on non BT and BT-cotton farms. Sarhad Journal of Agriculture, $\quad 32(4)$ : 267-274. DOI: http://dx.doi.org/10.17582/journal.sja/2016/32.4.267.274 FARRELL, M. J. (1957). The measurement of productive efficiency. Journal of the Royal Statistical Society, 120(3): 253-281. DOI: https://www.jstor.org/stable/2343100

FONTAN, C. (2008). Production et efficience technique des riziculteurs de Guinée: Une estimation paramétrique stochastique. Économie Rurale, 6(308): 19-35. DOI: http://journals.openedition.org/economierurale/342

FORTUCCI, P. (2003). The contribution of cotton to economy and food security in developing countries. United Nations Food and Agricultural Organization (FAO)
GOREUX, L. (2003). Le coton en zone Franc et les subventions Americaines et Europeennes: Avant et après chacun. Afrique Contemporaine 3(207): 59-70.

GOUDA, A. I., TOKO, I. I., SALAMI, S. D., RICHERT, M., SCIPPO, M. L., KESTEMONT, P., \& SCHIFFERS, B. (2018). Pratiques phytosanitaires et niveau d'exposition aux pesticides des producteurs de coton au nord du Benin. Cahiers Agricultures 27, 65002. DOI: https://doi.org/10.1051/cagri/2018038

HONFOGA, B. G. (2018). Diagnosing soil degradation and fertilizer use relationship for sustainable cotton production in Benin. Cogent Environmental Science, 4(1). DOI: https://doi.org/10.1080/23311843.2017.1422366

IMF. (2014). Inclusive growth in Burkina Faso: Selected issues. International Monetary Fund, Washington, DC JONDROW, J., LOVELL, C. A. K., MATEROV, I. S., \& SCHMIDT, P. (1982). On the estimation of technical inefficiency in the stochastic frontier production function model. Journal of Econometrics, 19(2-3): 233-238. DOI: https://doi.org/10.1016/0304-4076(82)90004-5

KARIMOV, A. A. (2014). Factors affecting efficiency of cotton producers in rural Khorezm, Uzbekistan: Reexamining the role of knowledge indicators in technical efficiency improvement. Agricultural and Food Economics, 2(1). DOI: https://doi.org/10.1186/s40100$\underline{014-0007-0}$

KARIMOV, A. A. (2012). Economic efficiency analysis of crop producing farm in Uzbekistan: Explanatory factors and estimation techniques. Cuvillier Verlag, Göttingen, Germany

KOFFI-TESSIO, E. (2000). Incitations et offre du coton au Togo: Une estimation économetrique. Économie $\begin{array}{lll}\text { Rurale } & \text { 257: 78-88. }\end{array}$ https://doi.org/10.3406/ecoru.2000.5183

KUNTZ, L., SCHOLTES, S., \& VERA, A. (2007). Incorporating efficiency in hospital capacity planning in Germany. European Journal of Health Economics, 8(3): 213-223. DOI: https://doi.org/10.1007/s10198-006-0021$\underline{6}$

LOVELL, C. A., \& SCHMIDT, P. (1988). A comparison of alternative approaches of the measurement of production efficiency. In Dogramaci A., and Färe (Eds.): Applications of modern production theory: Efficiency and productivity. Kluwe, Boston

LYFORD, C. (2009). An evaluation of the organic cotton marketing opportunity. Papier presenté à conference annuelle de l'association en Agriculture et de l'Économie Appliquée, Milwaukee, WI, 26-28 Juillet,

MENSAH, A. N. (2015). Cotton price change and welfare in Togo. Journal of Agriculture and Environment for International Development 109(1): 109-122. DOI: https://doi.org/10.12895/jaeid.20151.295

MEEUSEN, W., \& VAN DEN BROECK, J. (1977). Efficiency estimation from Cobb-Douglas production functions with composed error. International Economic Review 18(2): 435-444. DOI: https://www.jstor.org/stable/2525757

NARAYAN, S., \& BHATTACHARYA, P. (2019). Relative export competiveness of agricultural commodities and its determinants: some evidence from India. World Development, 117: 29-47. DOI: https://doi.org/10.1016/j.worlddev.2018.12.013 
NOUVELLE SOCIÉTÉ COTONNIÈRE DU TOGO (NSCT). (2017). Rapport Annuel de la Direction Régionale de Soutien à la production- Plateaux Nord (DRSP-PN) Campagne 2016-2017; 26 pages.

OLMSTEAD, A. L., \& RHODE, P. W. (2008). Biological innovation and productivity growth in the Antebellum cotton economy. NBER Working paper series, Cambridge, MA. https://www.nber.org/papers/w14142 PIESSE, J., \& THIRTLE, C. (2000). A stochastic frontier approach to firm level efficiency, technological change, and productivity during the early transition in Hungary. Journal of Comparative Economics, 28(3): 473-501. DOI: https://doi.org/10.1006/jcec.2000.1672

RAPIDEL, B., TRAORE, B.S., SISSOKO, F., LANÇON, J., \& WERY, J. (2009). Experiment-based prototyping to design and assess cotton management systems in West Africa. Agronomy for Sustainable Development 29: 545555.

DOI:

https://link.springer.com/article/10.1051/agro/2009016 RASSE, C., ANDRIEU, N., DIMAN J-L., FANCHONE, A., \& CHIA, E. (2018). Utilisation des pratiques agroecologiques et performances de la petite agriculture familiale: le cas de la Guadeloupe. Cahiers Agricultures 27, 55002. DOI: https://doi.org/10.1051/cagri/2018032 RIZOV, M., GAVRILESCU, D., GOW, H., MATHIJS, E., \& SWINNEN, J. (2001). Transition and enterprise restructuring: The development of individual farming in Romania. World Development 29(7): 1257-1274. DOI: https://doi.org/10.1016/S0305-750X(01)00030-4

SARKER, J. R., \& ALAM, F. (2016). Efficiency and economics in cotton production of Bangladesh. Journal of Agriculture and Environment for International Development, $\quad 110(2)$ : $\quad 325-348 . \quad$ DOI: https://doi.org/10.12895/jaeid.2016110.494

SAUER, J., \& BALINT, B. (2008). Distorted price and producer efficiency: the case of Romania. Journal of Productivity Analysis, 29(2): 131-142. DOI: https://doi.org/10.1007/s11123-007-0071-5

SAUER, J. (2006). Economic theory and econometric practice: parametric efficiency analysis. Empirical Economics 31: 1061-1087. DOI: https://doi.org/10.1007/s00181-006-0068-3

SEXTON, T. R., SILKMAN, R. H., \& HOGAN, A. J. (1986). Data envelopment analysis: critique and extensions. New Directions for Program Evaluation, 1986(32): 73-105. DOI: https://doi.org/10.1002/ev.1441 SHAFIQ, M., \& REHMAN, T. (2000). The extent of resource use inefficiencies in cotton production in Pakistan's Punjab: an application of the Data Envelopment Analysis. Agricultural Economics 22(3): 321-330. DOI: https://doi.org/10.1016/S01695150(00)00045-1

SUN, Z., \& LI, X. (2018). The trade margins of Chinese agricultural exports to ASEAN and their determinants. Journal of Integrative Agriculture, 17(10): 2356-2367. DOI: https://doi.org/10.1016/S2095-3119(18)62084-2
SNEYD, A. (2015). The poverty of "poverty reduction": the case of African cotton. Third World Quarterly: 36(1), 55-74.

DOI:

http://dx.doi.org/10.1080/01436597.2015.976017

SODJINOU, E., GLIN, L. C., NICOLAY, G., TOVIGNAN, S., \& HINVI, J. (2015). Socioeconomic determinants of organic cotton adoption in Benin, West Africa. Agricultural and Food Economics. DOI: https://doi.org/10.1186/s40100-015-0030-9

SOOMRO, A. W., SOOMRO, A. R., ARAIN, A. S., TUNIO, G. H., CHANG, M. S., LEGHARI, A. B., \& MAGSI, M. R. (2000). Response of cotton to various doses of NPK fertilizers. Pakistan Journal of Biological Sciences $3(9)$ : 1436-1437. DOI: https://doi.org/10.3923/pjbs.2000.1436.1437

TAIWO, A. M. (2019). A review of environmental and health effects of organochlorine pesticide residues in Africa. Chemosphere 220: 1120-1140. DOI: https://doi.org/10.1016/j.chemosphere.2019.01.001

THEODORIDIS, A., HASANOV, S., \& ABRUEV, A. (2014). Efficiency and productivity change analysis of cotton production in Uzbekistan. Outlook on Agriculture, 43(4): 259-263. DOI: https://doi.org/10.5367\%2Foa.2014.0186

VALDÉS, A., \& FOSTER, W. (2010). Reflexion on the role of agriculture in pro-poor growth. World Development, 38(10): 1362-1374. DOI: https://doi.org/10.1016/j.worlddev.2010.06.003

WEILL, L. (2002). Does restructuring improve banking efficiency in a transition economy? Applied Economics Letters, 9(5): 279-281. https://doi.org/10.1080/13504850110068125

WEILL, L. (2003). Banking efficiency in transition economies: The role of foreign ownership. The Economics of Transition 11(3): 569-592. DOI: https://doi.org/10.1111/1468-0351.00155

ZULFIQAR, F., \& THAPA, G. B. (2016). Is 'Better cotton' better than conventional in terms of input use efficiency and financial performance? Land Use Policy 52: 136-143. DOI: https://doi.org/10.1016/j.landusepol.2015.12.013

YANG, X., GENG, J., LI, C., ZHANG, M., CHEN, B. TIAN, X., ZHENG, W., LIU, Z., \& WANG, C. (2016). Combined application of polymer coated potassium chloride and urea improved fertilizer use efficiencies, yield and leaf photosynthesis of cotton on saline soil. Field Crops Research 197: 63-73. DOI: https://doi.org/10.1016/j.fcr.2016.08.009 